\title{
FAKTOR PENYEBAB KESALAHAN INTERPRETAS RADIOGRAFI KELAINAN DALAM RONGGA MUL
}

\section{Muliaty Yunus}

Bagian IImu Penyakit Mulut

Fakultas Kedokteran Gigi Universitas Hasanuddin

\begin{abstract}
For the interpretation of radiography image a good and define was needed radiography result ofthe^best quality. It's purpose have give the image became clearer and it was formed at the same object and the measure radiography result at the same of the original object. Radiography result is to decrease quality can be etiology factors in the interpretation of radiography error. The other factors can be doing because was not know of radiography image by normal anatomy structure in oral cavity.

The purpose of this paper is to describe etiology factors interpretation error of radiography result of intra oral anomaly.
\end{abstract}

Key words : Intra oral anomaly, Radiography image, Radiographyinterpretation.

\section{PENDAHULUAN}

Pada umumnya, interpretasi berdasarkan pada gambaran radiografi dari suatu penyakit. Gambaran radiografi yang spesifik tersebut, berhubungan dengan suatu penyakit. Jadi dengan mengerti tanda-tanda radiografi, setidaknya dapat membantu dan sebagai pendekatan yang baik untuk menginterpretasi hasil radiografi. Namun perlu diingat 
bahwa dalam menegakkan suatu dignosa, tidak hanya berdasarkan pada gambaran radiografi saja. Banyak penyakit yang mempunyai gambaran radiografi yang berbeda, tergantung pada tahap-tahap perkembangan penyakitnya. Oleh karena itu, dengan 1 menghubungkan antara pemeriksaan klinik dan Bantuan data laboratorium (kalau memang dibutuhkan) maka diagnosa akhir dapat ditegakkan.

Untuk menginterpretasi gambaran radiografi; dengan baik, tentunya diperlukan hasil radiografi yang berkualitas baik. Kualitas yang dimaksud 1 adalah memberikan gambaran yang tajam Qelas), $x$ gambaran yang terbentuk sama dengan objek dan ukuran hasil radiografi sama dengan ukuran

objek aslinya. Hasil radiografi yang kurang berkualitas dapat merupakan faktor penyebab kesalahan dalam menginterpretasi hasil radiografi. Sedangkan penyebab lain, dapat terjadi karena kurang dikenalinya gambaran radiografi struktur anatomi normal dalam rongga mulut.

Tujuan penulisan makalah ini, untuk menjelaskan faktor-faktor penyebab kesalahan menginterpretasi hasil radiografi kelainan dalam rongga mulut, sehingga dapat menghindari terjadinya salah diagnosa. :

\section{TINJAUAN PUSTAKA}

Keterampilan serta kecermatan dalam nfenafsirkan suatu radiografi diperlukan apabila ingin mendapatkan diagnosis klinis yang benar. Apabila hal tersebut belum dipenuhi, sedangkan pembuatan radiografi telah dilaksanakan, maka penentuan diagnosis bisa tidak tepat. ${ }^{1}$

Untuk menghindari kesalahan tersebut. maka sebelum menginterpretasi radiografi dalam rongga mulut, ada beberapa hal yang harus diperhatikan yaitu $:^{2}$ Radiografi rahang atas gigi belakang Cara menentukan radiografi apakah rahang atas atau rahang bawah adalah sebagai berikut:

a.Trabekula, jalannya ada yang 
horisontal dan ada yang vertikal, bentuknya seperti renda.

b. Tulang sigomatikus kalau terlihat merupakan gambaran radiopak yang berbentuk huruf $U$.

c. Terlihat sinus maksillaris.

d. Bentuk anatomi terutama bentuk anatomi molar pertama, akarnya adalah 3 .

e. Terlihat processus koronoideus apabila pembuatan radiografi pada regio molar ketiga.

f. Terlihat tuber maksillaris apabila pembuatanradiografi pada regio molar kedua atau ketiga.

\section{Radiografi rahang bawah gigi belakang}

a. Trabekula, jalannya horisontal.

b. Apabila terlihat Foramen mentalis, maka berada diantara premolar kedua dan molar pertama bawah atau premolar pertama dan premolar kedua bawah.

C. Terlihat kanalis mandibulars.

d. Bentuk anatomi, terutama molar pertama akarnya dua.

e. Linea obliqua interna dan eksterna kadang terlihat.

\section{Interpretasi radiografi.}

Interpretasiradiografi kelainan dalam rongga mulut haruslah mengikuti prinsip-prinsip sebagai berikut:

a. Yang utama dalam mendiagnosis kelainan darisuatu gigi adalah harus diperhatikan apakah gigi tersebut vital atau nonvital. Sebagai contoh, apabila gambaran dari periapikal gigi yang nonvital menunjukkan adanya radiolusen haruslah diperhatikan dengan cermat karena menggambarkan suatu keadaan, yang harus dirawat.

b. Kadang-kadang pada pengetesan vitalitas gigi tersebut nonvital akan tetapi pada pemeriksaan klinis tidak terlihat adanya karies, ternyata jaringan pulpanya nekrotik, ini kemungkinan disebabkan oleh trauma.

c. Apakah ada symptom neurologis, sebagai contoh apakah ada parastesi, sakit dan paralisis yang kemungkinan merupakan tanda suatu keganasan ataukah karena suatu trauma pada 


$$
\begin{array}{ll}
\text { bagian tersebut. Kerusakan } & \text { mengevaluasi hasil perawatan. } \\
\text { pada tulangkortikal, apakah } & \text { Untuk menunjang hal ini diperlukan } \\
\text { kerusakannya berlangsung } & \text { keterampilan serta kecermatan } \\
\text { cepat atau lambat karena dapat } & \text { dalam menafsirkan hasil suatu } \\
\text { diduga lesi tersebut suatu tanda } & \text { radiografi, sehingga diagnosis dapat } \\
\text { keganasan atau inflamasibiasa. } & \text { ditegakkan dengan tepat. }{ }^{2}
\end{array}
$$

d. Pada lesi periapikal yang radiolusen, aspirasi dari isi bagian tersebut diperlukan untuk diagnosis, karena dengan membedakan isi lesig>: tersebut, maka dapat dibedakan apakah kelainan tersebut kista atau bukan.

e. Apakah adanya lesi tersebut menyebabkan gejala sistemik ataukah tidak, karena penting untuk menentukan diagnosis banding dengan penyakit lain.

\section{PEMBAHASAN}

Sebelum

melakukan perawatan dan pengobatan gigi geligi dan mulut, maka kadangkadang diperlukan pembuatan radiografi gigi (Dental Radiogram). Dental radiogram ini memegang peranan yang penting dalam menegakkan diagnosis, merencanakan perawatan dan

\section{Kualitas Radiografi}

Kualitas radiografi atau kualitas diagnosa suatu gambar tampak dari hasil suatu radiografi, yang dipengaruhi oleh faktor densitas, kontras, ketajaman dan sejumlah distorsi (penyimpangan) dari gambar radiografi. Untuk mencapai hasil yang terbaik, sangat tergantung dari kemampuan operator untuk mengekspos film sesuai standar. Dengan kata lain seorang operator harus menguasai teknik-teknik radiografi dan pemrosesan film dengan baik dan benar. Apabila hal tersebut tidak tercapai maka hasil radiografi yang diperoleh kurang memberikan informasi yang tepat dalam menegakkan diagnosis pasti suatu penyakit.

Berikut ini akan diperlihatkan beberapa hasil radiografi yang 
kurang berkualitas. ${ }^{34}$

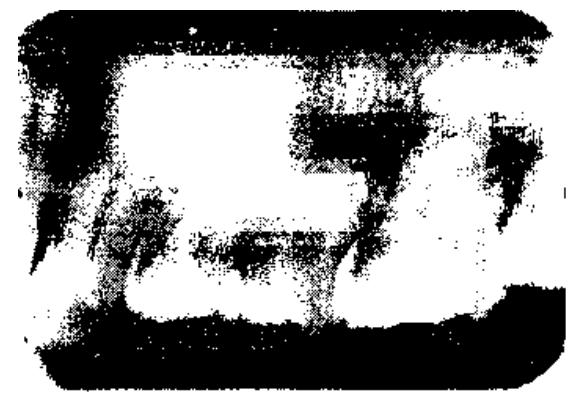

Gambar 1: Bayangan (cervical bum out)

Hal ini biasanya terjadi

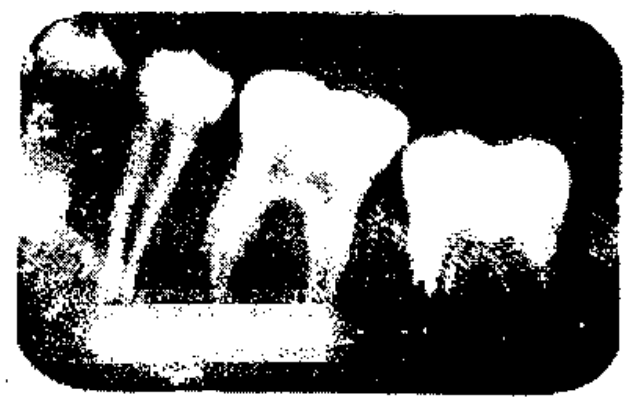

lingual dari servikal gigi tampak terpisah.Hal tersebut menghasilkan gambaran radiolusensi yang dapat "disalahartikan" sebagai Karies servikal atau karies akar.

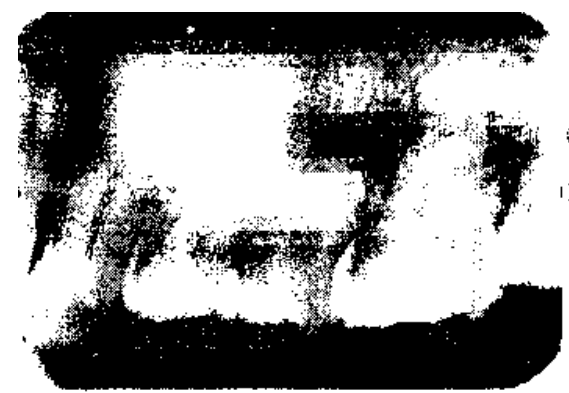

Gambar 2: Tampak akar gigi-gigi pemolar kabur. Hal ini menunjukkan adanya "angulasi horisontal yang tidak tepat" dari sinar radiografik dalam hubungannya dengan gigi-gigi tersebut.
Gambar 3: Gambaran gigi kabur Disebabkan :1. Pergerakan pasien

2. Pergerakan film.

3. Pergerakan mesin sinar $\mathrm{X}$
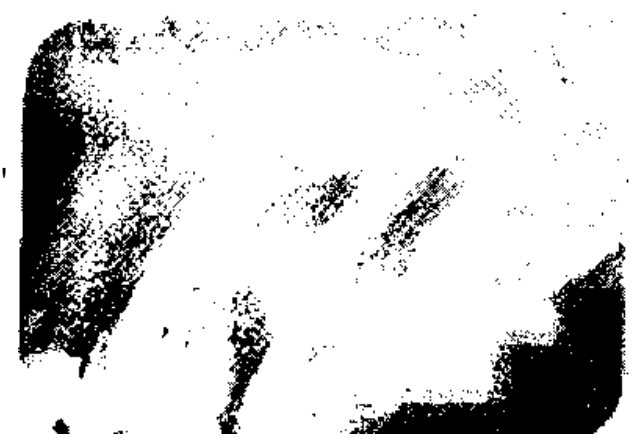

Gambar 4: Gambaran gigi memanjang

Disebabkan:"Pembengkokan yang berlebihan" dari setengah bagian posterior film, yang biasanya disebabkan oleh tekanan jari yang berlebihan dari pasien sewaktu menahan film.

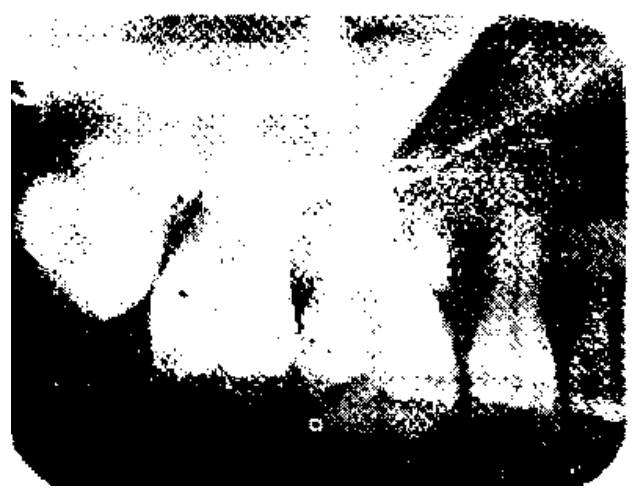

Gambar 5: Gambaran gigi memendek.

Disebabkan :

1. Pemendekan akar terjadi karena angulasi vertikal yang 
berlebihan.

2. Superimposisi dari arkus zigomatikpada apeks gigi molar atas.

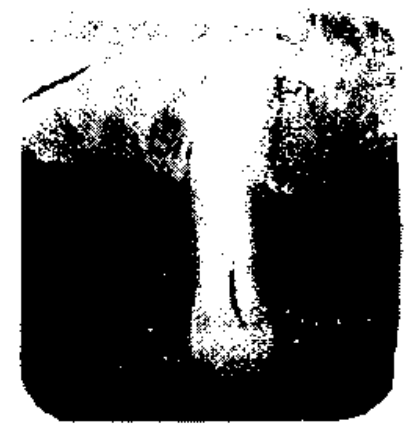

Gambar 6.Terlihat 1.Gigi elongasi 2. Artefak kuku jari

Perhatikan bahwa artefak yang sama terjadi sebagai akibat dari penekanan pada film atau sewaktu film dikeluarkan dari pembungkusnya sebelum diproses.

\section{Gambaran Radiografi Anatomi}

\section{Gigi Normal}

Diatas telah disebutkan bahwa yang perlu diperhatikan selain teknik atau cara mendapatkan hasil yang memuaskan, adalah menafsirkan atau menginterpretasikan hasil radiografi tersebut. Untuk menginterpretasikan hasil radiografi kelainan-kelainan intra oral, tentunya terlebih dahulu harus diketahui gambaran radiografi anatomi gigi yang normal.

Berikut ini akan diperlihatkan beberapagambaran radiografi dari anatomi gigi dan jaringan pendukungnya dalam keadaan normal,yang mana gambarangambaran tersebut biasanya disalahtafsirkan sebagai suatu kelainan. $^{2}$
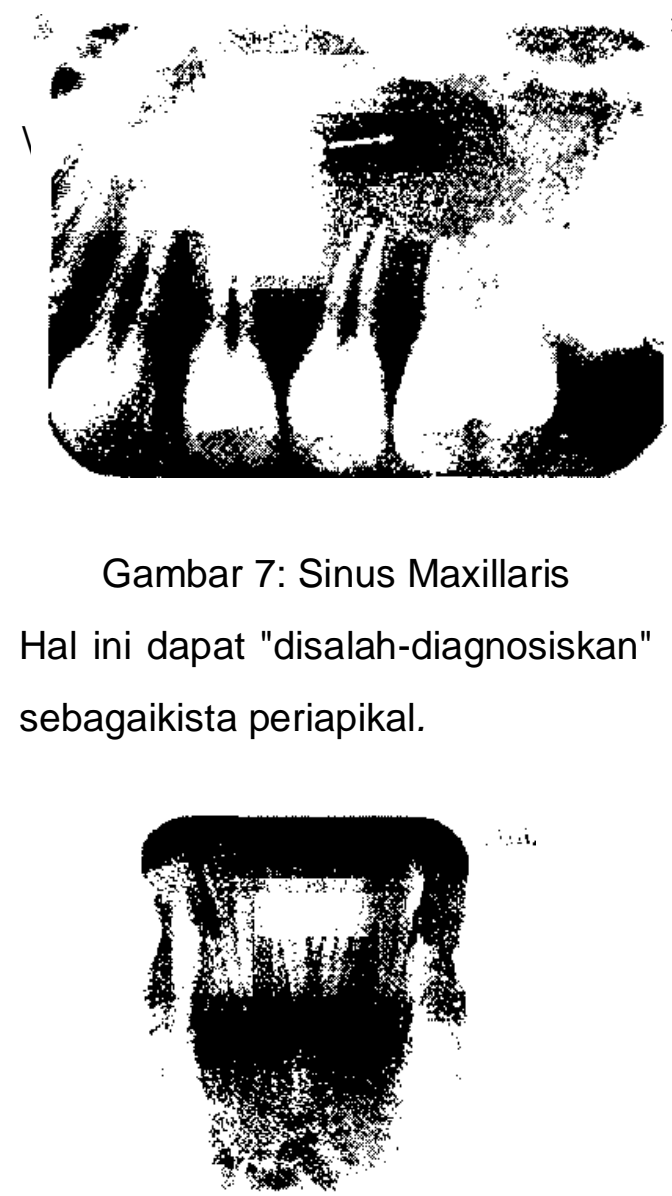
Berikut akan diperlihatkan

Gambar 8: Kanal-kanal nutrisi

Gambaran tersebut dapat
disalahtafsirkan sebagai garis
fraktur

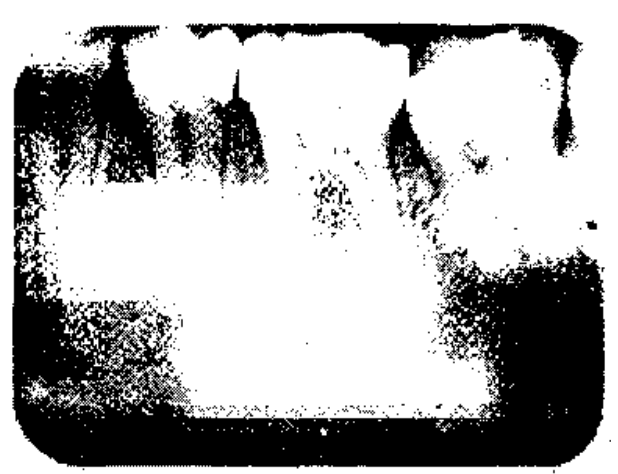

Gambar 9: Foramen mentale

Terlihat gambaran radiolusen dengan batas yang tegas pada apeks gigi premolar satu bawah. Gambaran ini dapat "disalahdiagnosikan" sebagai granuloma perapikal

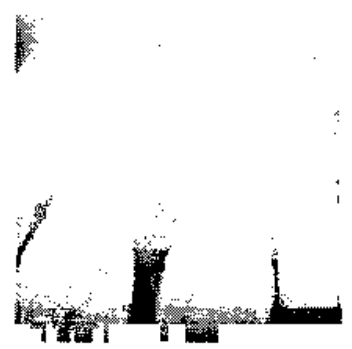

Gambar 10: Tanda panah 1. Foramen insisivum2. Garis bibir atas

Hasil-hasil Radiografi dari
Prosessing dan Teknik Radiografi
yang Kurang Tepat

beberapa contoh hasil radiografi yang gagal, sehingga kurang memberikan informasi yang tepat untuk dijadikan patokan dalam menegakkan diagnosa pasti suatu kelainan dalam rongga mulut.

Gambar 11 : Gambaran gigi memanjang dan garis radiolusen

1. Gambaran gigi memanjang (elongasi) disebabkan karena penempatan tube (sinar sentral) terlalu datar terhadap film.

2. Garis radiolusen terjadi karena film tergores penjepit film sebelum diprosessing.

Hal ini bisa disalahtafsirkan sebagai "garis

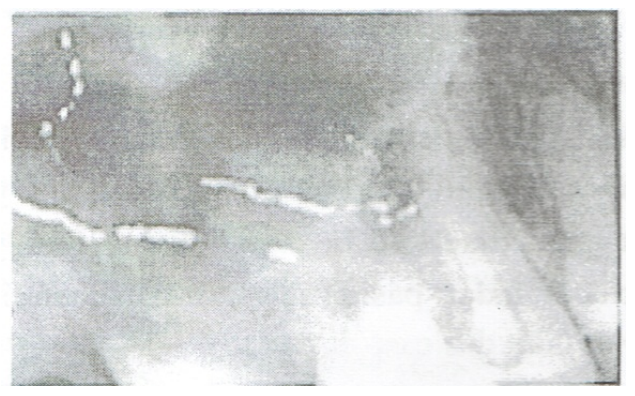


Gambar 12 : Gambaran artefak dan

Sinus Maksillaris

1. Gambaran artefak berupa garis radiopag disebabkan hasil radiografi tergores setelah prosessing.

2. Gambaran Sinus Maksillaris bisa disalah tafsirkan sebagai Kista Periapikal

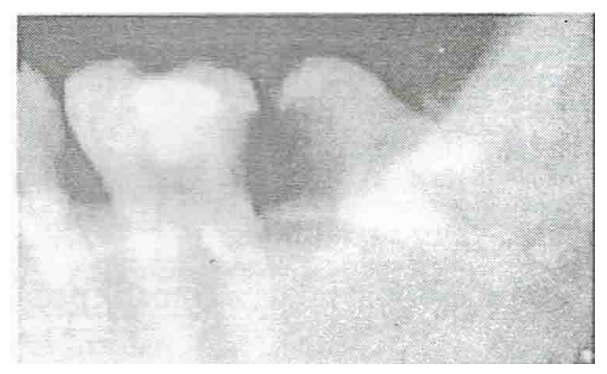

Gambar 13 : Gambaran gigi kabur Disebabkan pasien bergerak padasaat film diekspos.

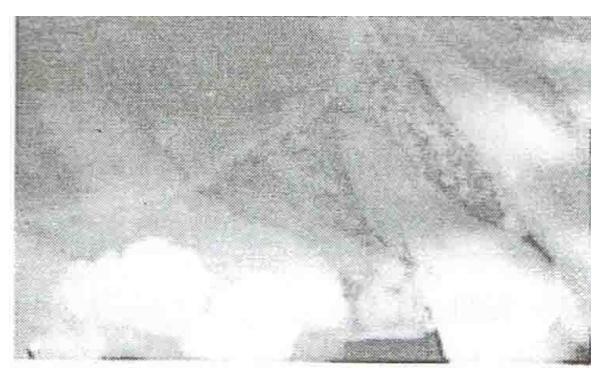

Gambar 14. Gambaran gigi memendek

Hal ini disebabkan penempatan ttfbe (sinar sentral) terlalu tegak terhadap posisi film.

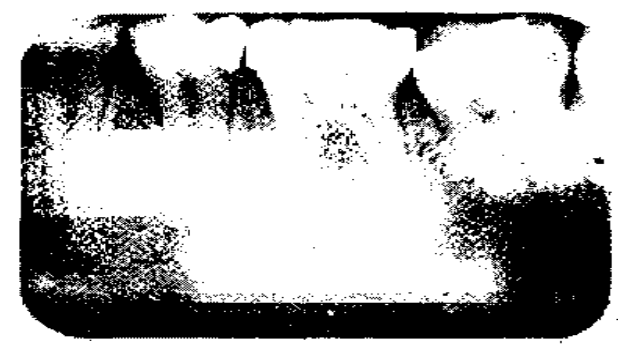

Gambar 15 : Gambaran gigi terpotong dan kabur

1. Disebabkan karena penempatan tube tidak terfokus.

2. Terlihat gambaran kabur karena pergerakan film.

\section{KESIMPULAN DAN SARAN}

Dalam bidang kedokteran gigi, pembuatan radiografi gigi biasa diperlukan untuk jnembantu menegakkan diagnosis, merencanakan perawatan dan mengevakuasi hasil perawatan. Untuk menunjang hal ini, diperlukan hasil radiografi gigi yang berkualitas baik disertai dengan keterampilan serta kecermatan dokter gigi dalam menafsirkan suatu hasil radiografi sehingga dapat terhindar dari "salah interpretasi, Lihatlah dengan benar dan baik apabila ingin menemukan sesuatu" adalah motto yang dipakai di Akademi Roentgenologi di Amerika.Ini berarti dalam pemeriksaan, menentukan diagnosis dan merencanakansuatu perawatan, radiografi gigi sangat diperlukan.

Dalam menginterpretasi hasil 
radiografi kelainan-kelainan intra oral, sebaiknya terlebih dahulu mengingat gambaran radiografi anatomi gigi dan jaringan pendukungnya secai"a normal, dan memperhatikan kualitas hasil radiografi, agar dapat menarik suatu diagnosis yang tepat.

\section{DAFTARPUSTAKA}

1. Goaz, P.W. dan White, S.C. 1987. Oral Radiology, Principle and Interpretation. Ed. Ke-2. The C.V. Mosby Company, S.T. Louis, Washington. D.C. Toronto, Him. 161 -199

2. Margono, G. 1998. Radiografi Intra-Oral, Teknik, Prosesing, Interpretasi Radiogram. Penerbit Buku Kedokteran EGC, Jakarta,
Him. 1-69

3. Mason, 1LA. IWJ. A Guide to Ttentha'i Radiography. Bristol, John Wright \& Son. LTD, Him. 29-75

4. Wuehrmann, A.H. dan MansonHing, L.R. 1981. Dental Radiology. Ed. Ke-3. The C.V. Mosby Company, S.T. Louis.

5. Toronto. London, 1981: 54-66; 425-453

6. Langlais, Kasle. 1996. Latihan Membaca Foto Rongga Mulut (Exercise in Oral Radiographic Interpretation). Ed. Ke-3. Hipokrates, Him. 1-37; 201-205. 